\title{
The clusterin paradigm in prostate and breast carcinogenesis
}

\author{
Federica Rizzi ${ }^{1,2}$ and Saverio Bettuzzi ${ }^{1,2}$
}

\begin{abstract}
1'Dipartimento di Medicina Sperimentale, Sezione di Biochimica, Biochimica Clinica e Biochimica dell'Esercizio Fisico, Università di Parma, Parma, Italy

${ }^{2}$ Istituto Nazionale Biostrutture e Biosistemi (I.N.B.B.), Roma, Italy

(Correspondence should be addressed to S Bettuzzi, Dipartimento di Medicina Sperimentale, Sezione di Biochimica, Biochimica Clinica e Biochimica dell'Esercizio Fisico, Università di Parma, Via Volturno 39, 43100 Parma, Italy; Email: saverio.bettuzzi@ unipr.it)
\end{abstract}

\begin{abstract}
The biological functions of clusterin (CLU, also known as ApoJ, SGP2, TRPM-2, CLI) have been puzzling the researchers since its first discovery in the early 80's. We know that CLU is a single 9 -exons gene expressing three protein forms with different sub-cellular localisations and diverse biological functions. Despite the many reports from many research teams on CLU action and its relation to tumourigenesis, contradictions in the data and alternative hypothesis still exist. Understanding the role of $C L U$ in tumourigenesis is complicated not only by the existence of different protein forms but also by the changes of tumours over time and the selection pressures imposed by treatments such as hormone ablation or chemotherapy. This review focuses on recent discoveries concerning the role of $C L U$ in prostate and breast cancer onset and progression. Although $C L U$ acts primarily as a tumour suppressor in the early stages of carcinogenesis, consistent with its role in the involution of the prostate following castration, late stage cancer may overexpress CLU following chemotherapeutic drugs or hormonal ablation therapy. High expression of secreted or cytoplasmic CLU may represent a pro-survival stimulus because it confers increased resistance to killing by anti-cancer drugs or enhances tumour cell survival in specific niches.
\end{abstract}

Endocrine-Related Cancer (2010) 17 R1-R17

\section{Introduction}

Clusterin (CLU) is an enigmatic glycoprotein with a nearly ubiquitous tissue distribution, apparently involved in many biological processes such as sperm maturation, tissue differentiation, tissue remodelling, membrane recycling, lipid transportation, cell-cell or cell-substratum interaction, cell proliferation and cell death. CLU is also believed to be involved in many pathological states such as neurodegeneration, aging and cancer (Rosenberg \& Silkensen 1995, Wilson \& Easterbrook-Smith 2000, Trougakos \& Gonos 2002, Shannan et al. 2006).

CLU was first isolated in ram rete testis fluid (Blaschuk et al. 1983, Fritz et al. 1983). After this first report, a wide range of tissues which can express this gene have been found (Fischer-Colbrie et al. 1984, Choi et al. 1989, de Silva et al. 1990a, James et al. 1991). Because of that, many different names have been given to CLU, often depending on the specific research issue.
It was first isolated in humans by Jenne \& Tschopp (1989) as complement cytolysis inhibitor (CLI), a protein which showed an high amino acid sequence homology $(75.6 \%)$ to rat sulfated glycoprotein-2 (SGP-2), one of the most important glycoprotein produced by rat Sertoli cells (Collard \& Griswold 1987) and suggested to play a role in sperm maturation. In the ventral prostate of rats, $C L U$ mRNA was first identified as testosterone-repressed prostate message-2 (TRPM-2; Montpetit et al. 1986). In 1989, Bettuzzi et al. (1989), after complete cDNA cloning, sequencing and comparison, have discovered that TRPM-2 was completely homologue to full-length SGP-2 cDNA. Just an year before, Cheng et al. (1988) found that SGP-2 was identical to CLU, a serum protein involved in aggregation of heterologous erythrocytes. Thus, the same cDNA/protein was finally found to be implicated in important biological phenomena so different as erythrocyte aggregation, 
complement activity, sperm maturation and prostate gland involution driven by androgen depletion. This protein is now officially called CLU according to a recent international consensus agreement.

$C L U$ was found dysregulated in many types of cancer, including prostate and breast cancer. The $C L U$ 'paradox' arises because a lot of data reported in scientific literature appear contradictory. The aim of this review is to give an answer to the main question: is $C L U$ a positive or a negative modulator of mammalian tumourigenesis? We attempt to reconcile the experimental results, although apparently contradictory, from the different laboratories in order to synthesise the $C L U$ 'paradigm' and render a complete picture of the role of $C L U$ in tumourigenesis.

\section{$C L U$ gene and transcripts}

In humans, the $C L U$ gene maps on chromosome 8 in a region that is frequently deleted in prostate cancer (8p21-p12). It is a unique gene, organised into nine exons of different size, spanning a region of $17877 \mathrm{bps}$.

Early studies of $C L U$ gene products reported divergent $5^{\prime}$-untranslated regions (5'-UTR) in RNAs from rats (Collard \& Griswold 1987, Wong et al. 1993), humans (Jenne \& Tschopp 1989, Kirszbaum et al. 1989, O'Bryan et al. 1990) and mice (French et al. 1993, Jordan-Starck et al. 1994). Therefore, the possibility of alternative first exons for $C L U$ transcription products in different mammalian species was already known at that time. Immediately after, Wong et al. (1994) characterised the human $C L U$ gene and identified a unique exon 1 sequence according to the genomic databases available at that time. However, these authors admitted that the data obtained are insufficient to rule out the possibility of alternative exon 1 usage. Until 2006, a very simple view prevailed, and it was commonly accepted that a unique transcript of about $1.9 \mathrm{~kb}$ came from transcription of the $C L U$ gene (de Silva et al. 1990a). Now, a recent GenBank update has earmarked two transcriptional isoforms of human $C L U$ called isoform 1, NM_001831.2 and isoform 2, NM_203339.1, which are listed as RefSeq. These two transcripts are probably originated from two initiation start sites and are only produced in humans and chimpanzees (Cochrane et al. 2007). Consulting the Alternative Splicing Annotation Project (ASAP) database (Lee et al. 2003) for the $C L U$ unigene cluster (Hs.75106) a third transcript, called isoform 11036, appears as one of the most probable mRNA variants (Andersen et al. 2007). Quite commonly in mammals, several genes produce distinct mRNA isoforms with heterogeneous $5^{\prime}$ ends. This can generate mRNAs that encode for the same protein, but have a different $5^{\prime}$-UTR. In some cases, when the translation start site exists within the first exon, it encodes for distinct protein with different, alternative or opposite biological activities. The $C L U$ gene seems to be a paradigmatic example of such complex regulation. The three isoforms previously cited contain nine exons, eight introns and a terminal 5'-UTR. Each of these transcripts has a unique fragment of exon 1 and shares the remaining sequence from exon 2 to exon 9, as shown in Fig. 1. Actually, isoform 1 is a $5^{\prime}$ extended sequence end of the previously published mRNA identified by the GenBank accession code M64722. Interestingly, in the complete sequence of exon 1, previously reported in a truncated form, Open Reading Frame Finder (ORF Finder: a software tool freely available at the NCBI web site) showed the presence of an additional functional AUG, unknown before. This mRNA is predicted to produce a putative protein of 501 amino acids of a molecular weight of $57.8 \mathrm{kDa}$. According to a computational prediction of its sub-cellular localisation by the PSORT program (Horton et al. 2007), this putative CLU form has a prevalent cytoplasmic/nuclear localisation and may account for the existence of an intracellular form of CLU escaping the secretory pathway. Dissimilarly, isoform 2 has an alternative untranslated exon 1. The AUG of the main ORF is located in exon 2, in a region common to the three transcripts and immediately upstream of a functional endoplasmic reticulum (ER) localisation leader sequence. This mRNA is predicted to produce the protein of 449 amino acids targeted to secretion, which is the most extensively studied form of CLU (de Silva et al. 1990a,b, Burkey et al. 1991, Choi-Miura et al. 1992). All the transcripts described possess a third AUG that is again in frame with the others and localises on exon 3. Leskov et al. (2003) found an alternative mRNA in MCF-7 mammary

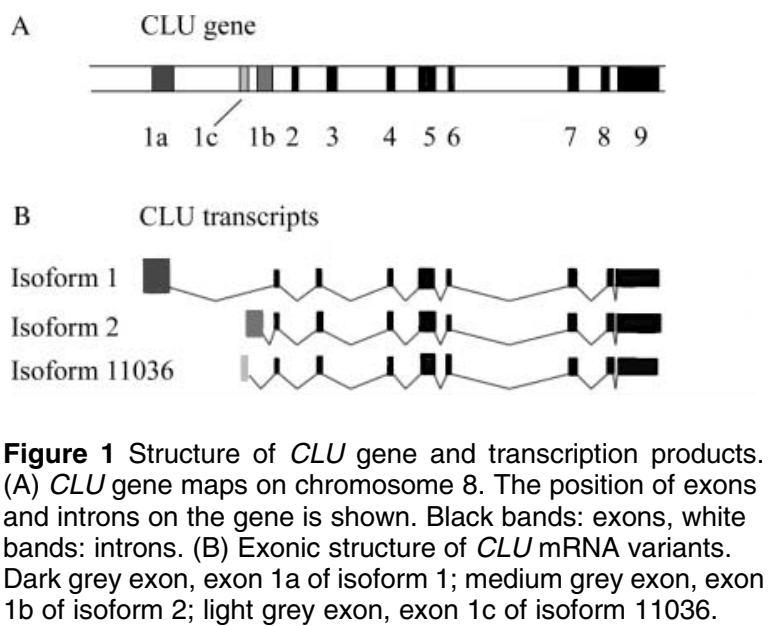


cancer cells in which the exon 1 of isoform 1 is directly joined to exon 3 , therefore lacking exon 2, and consequently both the AUG and the ER localisation sequence contained in this exon. The authors found that this alternative mRNA is constitutively expressed in MCF-7 cells at very low levels, coding for a precursor protein called pnCLU, a putative nuclear pro-death form. Since its discovery, its existence has never been confirmed later in other cell lines or tissues (Andersen et al. 2007, Cochrane et al. 2007, Schepeler et al. 2007), and it is not one of the most probable splicing variant according to the ASAP database. Therefore, it should be seriously considered that this transcript is either very specific to MCF7 cells (for reasons still unknown) or an experimental artefact.

The accumulation of evidence now confirms the existence of the previously described CLU transcripts (i.e. isoform 1, isoform 2 and isoform 11036), rendering the idea that the human $C L U$ gene produces a unique transcript obsolete. Cochrane et al. (2007) found that isoform 1 and isoform 2 are concomitantly expressed in prostate cancer cell lines, but are differentially regulated by androgens. Isoform 1 is down-regulated by androgens, whereas isoform 2 is up-regulated by androgens and its level increases during the progression to androgen-independent prostate cancer in LNCaP xenograft tumours. Recently, Andersen et al. (2007) and Schepeler et al. (2007) have confirmed that all the three $C L U$ mRNA variants, i.e. isoform 1, isoform 2 and isoform 11036, are expressed in various cell types including prostate and breast cancer cell lines. The same research team found that different signalling pathways affect $C L U$ mRNA isoforms production. In particular, they found that the Wnt signalling pathway, via TCF 1 , specifically regulates the expression levels of isoform 1 but not those of isoform 2 (Schepeler et al. 2007).

\section{CLU protein forms}

It is now clear that $C L U$ encodes more than one mRNA and that several protein forms derive from the unique gene, but what still remains to be defined is how each transcript, discussed above, relates to the diverse CLU forms observed at the protein level.

Recent information about the pathway of CLU degradation has given knowledge about the basic metabolism of this protein in the cell. In prostate cancer PC 3 cells, the half-life of CLU is $<2 \mathrm{~h}$. Rapid degradation occurs through the proteasome. Rapid degradation may be the main way prostate cancer cells avoid accumulation of CLU and escape apoptotic death (Rizzi et al. 2009a).

\section{Secreted CLU}

The most extensively studied form of CLU is the secreted form (sCLU), a 75-80 kDa glycosylated $\alpha$ - $\beta$-heterodimer present in almost all physiological fluids, consisting of two chains of about $40 \mathrm{kDa}$ each, linked by five disulphide bonds (de Silva et al. 1990a). sCLU translation starts from the AUG located in the second exon and produces a precursor protein of $49 \mathrm{kDa}$. This protein is directed to the ER by a leader signalling sequence. Then the protein is transported to the Golgi, heavily glycosylated and cleaved, generating two chains tightly bound by five disulphide bridges (Kirszbaum et al. 1992). The partially glycosylated, uncleaved protein is detectable as a $60 \mathrm{kDa}$ band by SDS-PAGE. There is now substantial evidence that sCLU has a chaperone action like that of the small heat shock proteins and is one of the first described extracellular chaperones (Kirszbaum et al. 1989, Humphreys et al. 1999, Poon et al. 2000, Wilson \& Easterbrook-Smith 2000, Lakins et al. 2002).

Sequence analysis of sCLU reveals several motifs that may be important for its chaperone action. Amphipathic $\alpha$-helices located at the $\mathrm{N}$-terminus of the $\alpha$-subunit and at both the $\mathrm{N}$ - and $\mathrm{C}$-termini of the $\beta$-subunit possess hydrophobic surfaces that are believed to mediate the binding of CLU to hydrophobic ligands (Law \& Griswold 1994). It has been hypothesised that CLU has a flexible binding site (Bailey et al. 2001) due to the combination of an intrinsically disordered region and amphipathic $\alpha$-helices ordered structures as shown in Fig. 2.

\section{Intracellular CLU (nCLU and cCLU)}

In their pioneering work, Reddy et al. presented the first experimental evidence showing that, in addition to the secreted form of the protein, a nuclear form of CLU (nCLU) exists. The intracellular form of the protein was found to be induced in response to treatment with
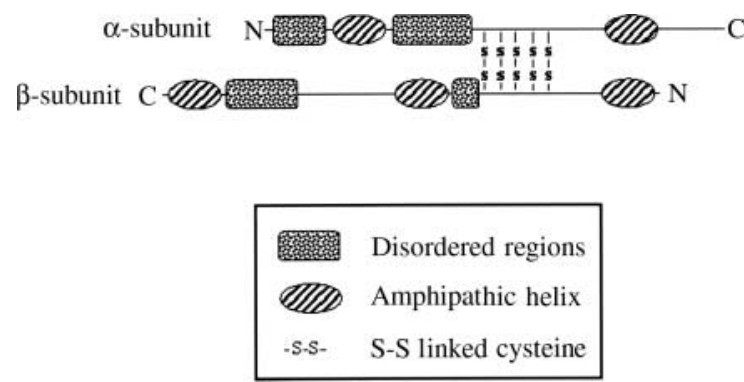

Figure 2 Location of ordered and disordered regions in the CLU protein. 
transforming growth factor $\beta$ (TGF- $\beta$ ) of epithelial cell lines (Reddy et al. 1996). A few years later Yang et al. (2000) identified a $55 \mathrm{kDa}$ nuclear form of CLU induced by ionizing radiation (IR) in MCF-7:WS8 breast cancer cell line. Other authors later confirmed that a shorter uncleaved, unglycosylated CLU protein of $45-55 \mathrm{kDa}$ is usually detected concomitantly with the immunohistochemical detection of CLU inside the nucleus (Leskov et al. 2003, Caccamo et al. 2005). The origin of the cytoplasmic (cCLU) and nCLU proteins is currently the subject of intensive research in cancer.

Various mechanisms have been proposed to explain the presence of CLU in the nuclear and cytosolic compartments including: 1) alternative initiation of transcription in epithelial cell lines stimulated with TGF- $\beta$ (Reddy et al. 1996); 2) alternative splicing in MCF-7 cells exposed to IR (Leskov et al. 2003); 3) alternative translation in prostate cancer cells (Moretti et al. 2007); 4) retrotranslocation from the Golgi apparatus to the cytosol via an ERAD-like pathway in stressed cells (Nizard et al. 2007); 5) re-internalisation of sCLU from the extracellular milieu into the cytosol (Kang et al. 2005). In addition, we found that removal of the leader sequence from sCLU cDNA led to the production of a $49 \mathrm{kDa}$ protein band in epithelial prostate cell lines (PC3 and PNT1A). This molecular weight corresponds to the expected size of the non-glycosylated and uncleaved protein form (Scaltriti et al. 2004b).

It is important to note that none of these studies have isolated and sequenced the intracellular forms, therefore it is not known if CLU proteins of different mass result from alternative splicing or transcription initiation or simply represent species at different stages of maturation (e.g. cleaved or uncleaved, at different stages of glycosylation). At the moment we do not have definitive experimental data illustrating which structural characteristics and domains are specific for each different protein product. We also do not know exactly which domains are necessary for nuclear targeting, since at least three nuclear localisation signal, present in the human CLU amino acid sequence, have been identified but found not to be necessary for nuclear targeting (Scaltriti et al. 2004b). So, while we have a rough idea about the structure of sCLU, we still do not know how nCLU looks like. Nevertheless, it seems reasonable that the biological role of CLU outside and inside the cell is different.

It is now generally accepted that expression of nCLU is associated with cell death, as demonstrated in both prostate (Caccamo et al. 2003, 2005, Moretti et al. 2007) and breast cancer cell lines (Yang et al. 2000,
Leskov et al. 2001). It has been proposed that nCLU binds the Ku70/Ku80 complex, a nuclear DNA end binding heterodimer, interfering with DNA doublestrand breaks repair systems (Yang et al. 2000).

\section{Regulation of $C L U$ gene expression by oncogenes, oncoproteins and epigenetic factors}

$C L U$ is the prototypical multifunctional gene: regulating apoptosis, cell-cell interactions, protein stability, cell signalling, proliferation and, finally, transformation. In spite of the multiple functions that have been ascribed to $C L U$, its genetic inactivation in mice is well-tolerated and CLU knockout (CluKo) mice develop and live normally (McLaughlin et al. 2000).

$C L U$ expression is regulated by many cis-acting elements and trans-factors which may be responsible for the complex tissue-specific control of the gene (Michel et al. 1997). Trans-factors that have been shown to interact with the $C L U$ promoter and regulate its activity include: Egr-1 (Criswell et al. 2005), members of the AP-1 complex (Jin \& Howe 1999), HSF1/2 (Loison et al. 2006) and B-Myb (Cervellera et al. 2000).

\section{CLU expression and growth factors signalling}

TGF- $\beta$ positively modulates $C L U$ expression via activation of an AP-1 site in the mammalian $C L U$ promoter through the removal of the trans-repression effect of c-Fos by TGF- $\beta$ (Jin \& Howe 1999). More recently, it has been demonstrated that exposure of keratinocyte cells to vanadium induces apoptosis, c-Fos expression and a switch from sCLU to nCLU (Markopoulou et al. 2009). CLU is up-regulated twice during mouse mammary gland development: the first time at the end of pregnancy and the second time at the beginning of the involution. Therefore, it represents a marker of mammary epithelial cell differentiation. The second and most dramatic up-regulation of $C L U$ coincides with the potent induction of TGF- $\beta 1$, dependent on $\beta 1$-integrin ligand-binding activity (Itahana et al. 2007).

IR activates TGF- $\beta$ signalling in many cell types and tissues, including epithelial cells. Direct transcriptional activation of the $C L U$ gene as a result of an activated TGF- $\beta 1$ pathway may result in production of both sCLU and nCLU in MCF-7 breast cancer cells (Yang et al. 2000, Klokov et al. 2004). Ionizing irradiation activates a signalling pathway that emanates from two growth factors receptors: epidermal growth factor receptor (EGFR) and insulin-like growth factor 
receptor (IGFR) (Yang et al. 2000). It was subsequently demonstrated that IGFR, but not EGFR, mediates the induction of sCLU in response to irradiation (Criswell et al. 2005). In this context, sCLU is induced as a protective response to damaging stress since knockdown of CLU by RNA interference accelerates cell death (Criswell et al. 2005).

\section{CLU expression and oncogenes}

Several studies show that $C L U$ is regulated by oncogenes and oncoproteins. The first evidence that $C L U$ expression is modulated by oncogenic activity was published in 1989, which reported that a thermally inducible gene, orthologue of rat $C L U$, was activated by retroviral oncogenes such as v-src, v-fps and v-mil (Michel et al. 1989). Induction by the oncogenic kinases was dependent on the AP-1 binding site.

Klock et al. published the first study demonstrating the role of two classical proto-oncogenes, namely $c-M y c$ and $H$-Ras in regulating $C L U$ expression. It was reported that overexpression of H-Ras, but not of $c-M y c$, caused repression of $C L U$ expression at the mRNA level in the rat embryo fibroblast cell line Rat-1 (Klock et al. 1998). CLU is up-regulated when H-Ras is down-regulated (Kyprianou et al. 1991) in human MCF-7 breast cancer cells. Analysis of gene expression in rat fibroblasts transformed with activated $H$-Ras confirmed that $C L U$ is one of the most significantly down-regulated genes (Lund et al. 2006).

Although it was initially thought that $c-M y c$ could not regulate the expression of $C L U$ (Klock et al. 1998), the group lead by Andrei Thomas-Tikhonenko et al. (2004) reported that ectopic levels of $c-M y c$ could strongly repress the expression of $C L U$ in murine colonocytes or human keratinocytes, and forced overexpression of $C L U$ could inhibit, at least partially, $c$-Myc-dependent tumourigenesis. It has been recently shown that also $N-M y c$, similar to $c-M y c$, is a negative regulator of $C L U$ (Chayka et al. 2009).

The mechanisms of repression by $M y c$ family members appear to be complex and are still a matter of active investigation. On the other hand, recent studies suggest that Ras-mediated silencing of $C L U$ is epigenetic (Lund et al. 2006). Ras induces deacetylation of the CLU promoter followed by methylation of a $\mathrm{CpG}$ island placed $14.5 \mathrm{~kb}$ upstream of the transcription start site (Lund et al. 2006).

A plausible hypothesis to explain the fact that oncogenes generally down-regulate CLU is that suppression of $C L U$ expression is required for oncogene-dependent transformation.

\section{Epigenetic regulation of CLU expression in cancer}

Other research groups have observed epigenetic silencing of $C L U$ in transformed cells and cancer tissues. $C L U$ is methylated in the transgenic adenocarcinoma of mouse prostate (TRAMP)-C2 murine prostate cancer cell line, as well as in the human prostate cancer cell line $\mathrm{LNCaP}$. $C L U$ expression is significantly reduced in untreated and hormonerefractory human prostate carcinomas with respect to normal tissue (Rauhala et al. 2008). At the moment, we do not have experimental evidence of this mechanism in breast cancer cell lines, but further support of this hypothesis comes from the work by Nuutinen et al. (2005), who show that $C L U$ transcription is silenced by gene methylation and deacetylation in human neuroblastoma and neuronal cell lines. A similar mechanism of epigenetic regulation has also been described in tumour-conditioned endothelial cells (Hellebrekers et al. 2007). In this system, $C L U$ is significantly down-regulated through histone H3 deacetylation and loss of H3 lysine-4 methylation. Proliferation of endothelial cells was significantly induced upon down-regulation of $C L U$, indicating that this gene inhibits endothelial cell growth. Finally, three-dimensional sprouting of endothelial cell spheroids in a collagen gel was significantly increased by down-regulation of $C L U$, suggesting that $C L U$ expression is inversely related with neoangiogenesis and cells sprouting.

\section{CLU and NF- $\kappa B$ signalling}

Nuclear factor $\kappa \mathrm{B}(\mathrm{NF}-\kappa \mathrm{B})$ is a multifunctional transcription factor that has a central importance in immunity and cancer. NF- $\kappa \mathrm{B}$ is activated in response to external stimuli, (i.e. engagement of the tumour necrosis factor receptor by its ligand), by the I $\mathrm{K}$ kinases $\alpha, \beta$ and $\gamma$, which phosphorylate the inhibitors of NF- $\kappa B$ (I $\kappa \mathrm{Bs}$ ), liberating a transcriptionally active NF- $\kappa \mathrm{B}$ molecule. The first evidence that NF- $\kappa \mathrm{B}$ regulates $C L U$ expression was provided by a study aimed to systematically analyse and isolate all NF- $\kappa \mathrm{B}$ target genes in mouse embryo fibroblasts. Among the plethora of genes activated by NF- $\kappa \mathrm{B}, C L U$ was one of the most highly regulated genes (Li et al. 2002). Interestingly, knockout of any one of the three IKKs resulted in lack of activation of $C L U$, suggesting that its activation is dependent on the whole NF- $\kappa \mathrm{B}$ signalosome.

But the effects of NF- $\mathrm{B}$ signalling on $C L U$ expression are more complex, and interestingly it was later shown that $C L U$ regulates $\mathrm{NF}-\kappa \mathrm{B}$ activity in a negative manner by stabilising the inhibitor $\mathrm{I} \kappa \mathrm{Bs}$ 
(Santilli et al. 2003, Devauchelle et al. 2006, Savkovic et al. 2007, Takase et al. 2008a,b). By western blot analysis, we have observed an increased expression level of I $\kappa \mathrm{B} \alpha$ and a reduced expression of NF- $\kappa \mathrm{B}$ also in PNT1A human immortalised prostate epithelial cells stably overexpressing $C L U$ compared with control cells transfected with empty vector (Bettuzzi et al. 2009). Confocal microscopy has confirmed that $C L U$ overexpression has caused cytoplasmic accumulation of p65. All these evidences lead to the hypothesis that $C L U$ participates in a negative loop in which transcriptional activation of $C L U$ is evoked to dampen NF- $\kappa \mathrm{B}$ activity.

Notably, key pro-survival/proliferation NF- $\mathrm{B}$ target genes, such as $p-A K T$, cyclin $D 1$ and $B C L 2$, were down-regulated in the presence of exogenous CLU. In contrast, expression of the growth suppressor p21 was increased and a robust slow-down of the cell cycle was detected in CLU-transfected PNT1A cells (Bettuzzi et al. 2009).

\section{$C L U$ expression in prostate and breast cancer}

It is now evident that changes in $C L U$ expression are important events in cancer development, but the specific role of $C L U$ in tumourigenesis is still a matter of debate. In different kinds of cancers, $C L U$ has been reported to be up- or down-regulated (Redondo et al. 2000, Xie et al. 2002, 2005, Zhang et al. 2003, Chen et al. 2004, Pucci et al. 2004). We have found that $C L U$ mRNA and protein products are down-regulated in both low-grade and high-grade prostate cancer (Bettuzzi et al. 2000, Scaltriti et al. 2004a, Rizzi et al. 2008). The study was conducted in surgical prostate specimens from patients affected by prostatic adenocarcinoma graded from 1 to 5 (Scaltriti et al. 2004a). CLU was down-regulated in tumour samples in comparison with benign-matched tissues. In benign tissue, both epithelial and stromal cells express $C L U$, but the staining is stronger in the stromal compartment. In low-grade prostate cancer, CLU is colocalised with GAS-1 (a marker of cell quiescence) in the stromal compartment and accumulates in the basal lamina. In high-grade tumours, CLU stains the remnants of stromal matrix, while epithelial cancer cells were rarely positive. When seen in these cells, CLU staining is confined to the cytoplasm. It might be hypothesised that extracellular CLU protein secreted by stromal cells is involved in tissue remodelling processes during stromal compartment involution due to cancer progression. Others confirmed the intense staining for CLU in stromal cells, and found that only CLU staining of stroma was associated with prostate cancer recurrence (Pins et al. 2004). Interestingly, some years later Tomlins et al. (2007) used laser microdissected samples and found that $C L U$ gene is differentially expressed in the stroma and in the epithelium, being more expressed in the stromal compartment. These results showing high-CLU distribution in the stromal compartment associated to down-regulation in the tumour cells disagree with earlier data reported by July et al. (2002). In their work, the authors show that $C L U$ expression is limited to the epithelial compartment, being significantly higher in prostate cancer of patients who received neoadjuvant hormone therapy and suggesting that CLU could play an important role in the onset of castration-resistant disease. This discrepancy may be explained by the existence of different CLU forms. The possibility that they may undergo specific changes of expression during the different phases of neoplastic transformation must also be considered. Furthermore, sub-cellular localisation of CLU might also be an important key to define its biological functions. At the moment, we cannot rule out the possibility that $C L U$ might act as a negative tumour modulator in the early stage of prostate cancer, while being recruited as a positive tumour growth modulator in the more advanced stages. This may very likely happen during the onset of androgen and chemotherapy resistance.

Oncomine is a public database containing a large collection of gene expression experiments on human cancer (Rhodes et al. 2004). We have interrogated this database to understand whether $C L U$ is up- or downregulated in prostate cancer $(\mathrm{PCa})$. The meta-analysis of available data showed that $C L U$ mRNA is differentially expressed in cancer tissue compared with normal prostate. In 14 out of 15 independent studies comparing benign tissue to prostate cancer, $C L U$ was found significantly down-regulated (the results of 12 studies with the most significant results $(P<0.0001)$ are shown in Fig. 3A).

Remarkably, $C L U$ expression is inversely proportional to the grade and/or metastatic stage of $\mathrm{PCa}$ in eight out of eight studies (the result of one study is shown in Fig. 3B; the complete set of experiments can be seen at www.oncomine.org).

Redondo et al. (2000) studied CLU expression in breast cancer. They studied 114 formalin-fixed/ paraffin-embedded invasive breast carcinoma samples and 40 normal glandular epithelia controls. They used a non-commercially available antibody anti-human CLU for this study; the specificity of this antibody was previously evaluated in western blot analysis but not in immunohistochemistry analysis (IHC) by the researchers who developed the antibody (Murphy et al. 1988). 

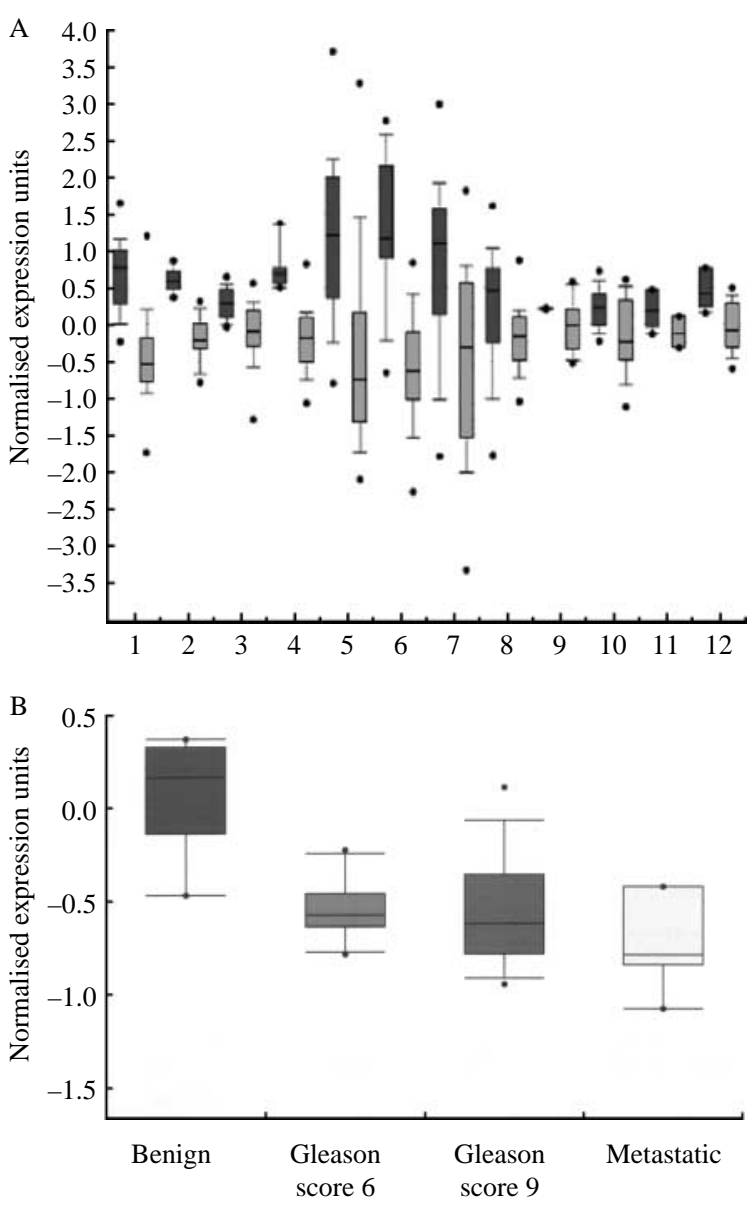

Figure $3 \mathrm{CLU}$ expression is down-regulated in prostate cancer. (A) Meta-analysis of available microarrays data on the Oncomine website. CLU mRNA is significantly down-regulated in prostate cancer tissue compared with normal prostate. Box plot analysis of 12 studies and associated references are shown: 1, LaPointe et al. (2004); 2, Welsh et al. (2001); 3, Yu et al. (2004); 4, Vanaja et al. (2003); 5, Dhanasekaran et al. (2001); 6, Dhanasekaran et al. (2005); 7, Tomlins et al. (2007) 8, Singh et al. (2002); 9, LaTulippe et al. (2002); 10, Luo et al. (2002); 11, Varambally et al. (2005); 12, Holzbeierlein et al. (2004). Dark grey boxes, CLU expression in normal tissues; medium grey boxes, $C L U$ expression in cancer tissues. (B) $C L U$ expression is inversely proportional to the Gleason grade and metastatic stage of prostate cancer. The box plot representation is from the study by Vanaja et al. (2003).

$C L U$ expression was scored positive when more than $10 \%$ of tumour cells showed staining. The expression of $C L U$ in normal epithelial cells was always negative and $53 \%$ of tumour samples showed a positive staining for CLU. The authors also found a positive correlation between the extent of the reaction and the tumour size, and a negative correlation with the status of progesterone and oestrogen receptors expression. On the other hand, they did not find any correlation between CLU immunostaining and cancer stage or prognosis. A more recent study has evaluated $C L U$ expression in 141 breast cancer samples using a commercially available antibody (Kruger et al. 2007). As in the study by Redondo et al., CLU staining was considered positive when found in at least $10 \%$ of the cancer cells. Normal tissue was not included in the experimental design of this work, so this study does not really answer the basic question whether $C L U$ is up- or down-regulated in breast cancer. Positive CLU staining was found in $26 \%$ of the tumours analysed. Significant correlation was found with histological tumour grade. It must be stated that the same data also show that the remaining $74 \%$ of tumour samples were negative for $C L U$ expression. Therefore, further studies are required to understand whether $C L U$ is expressed only in some specific sub-sets of breast cancer, or whether adjuvant radiotherapy has significantly affected $C L U$ expression in primary tumours. This is predictable since X-ray irradiation potently enhances $C L U$ expression in tissues (Yang et al. 2000, Klokov et al. 2004).

We interrogated the Oncomine database again to explore whether $C L U$ mRNA is up- or down-regulated in breast cancer. Nine studies show that $C L U$ is differentially expressed in breast cancer samples versus normal/benign tissues. In all of these studies, CLU mRNA is down-regulated in cancer tissue with respect to normal/benign tissue (Fig. 4A). As in the case of prostate cancer, $C L U$ is down-regulated as a function of the tumour grade, being more repressed in poorly differentiated tumours (Fig. 4B).

\section{Hormone-refractory and metastatic cancers: the challenge of CLU antisense therapy}

Localised prostate disease is generally managed by surgery or local radiation therapy. About one third of the patients treated with conventional clinical protocols will develop metastases and undergo androgen ablation therapy. Unfortunately, too often the disease progresses towards the resistant phenotype turning to a hormone-independent state, also called castrationresistant prostate cancer (CRPC). CRPC is unresponsive to further hormonal therapy and prognosis is very poor (median survival is $\sim 1$ year). Breast cancer is commonly treated by various combinations of surgery, radiation therapy, chemotherapy and hormone therapy. In general, at the beginning of therapy, systemic agents are active, being effective in $90 \%$ of primary breast cancers and $50 \%$ of metastases. However, after a variable period of time, progression occurs. At that point, resistance to therapy is not only common, but unfortunately expected (Gonzalez-Angulo et al. 2007). 

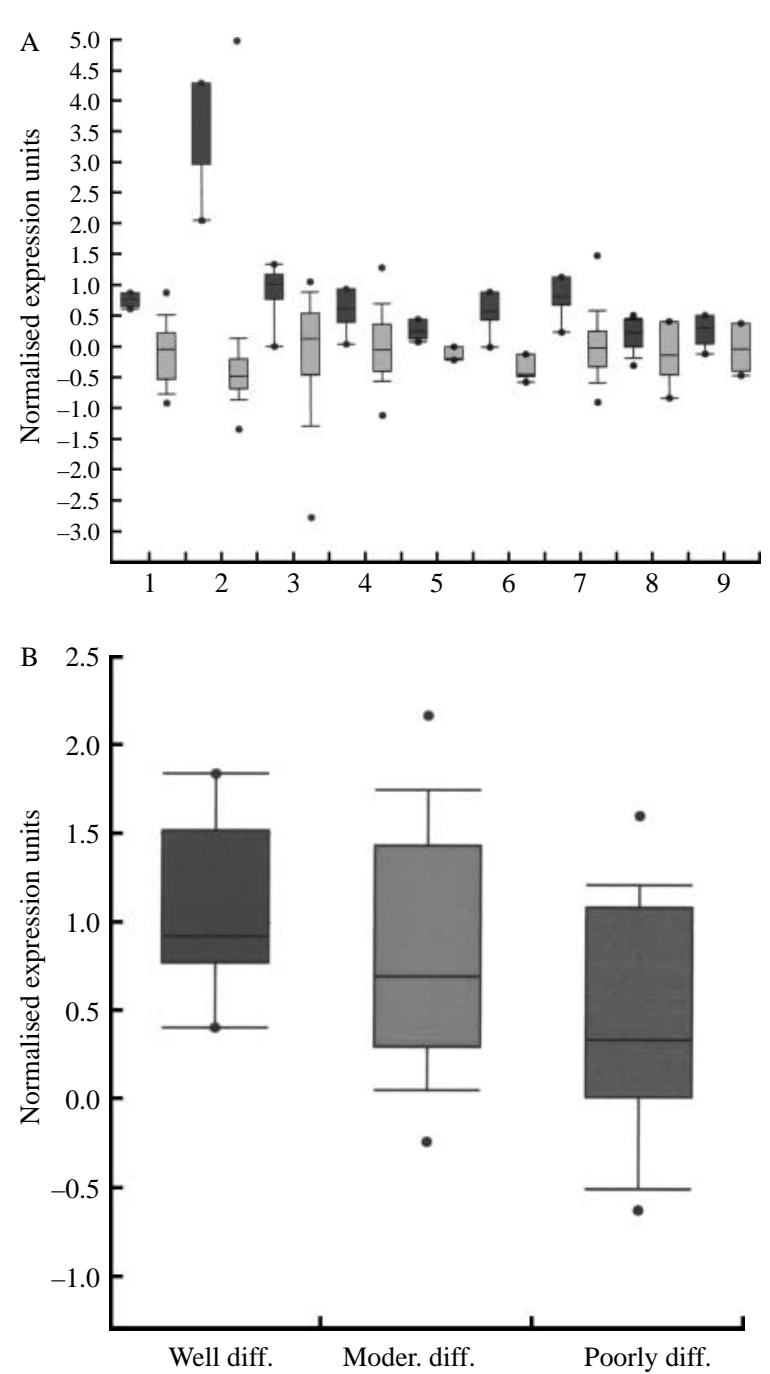

Figure 4 CLU expression is down-regulated in breast cancer. (A) Meta-analysis of available microarrays data on the Oncomine website. CLU mRNA is significantly down-regulated in breast cancer tissue compared with normal breast. Box plot analysis of 9 studies and associated references are shown: 1, Richardson et al. (2006); 2, Finak et al. (2008); 3, Radvanyi et al. (2005); 4, Sørlie et al. (2001); 5, Turashvili et al. (2007) (lobular cancer); 6 and 7, Perou et al. (2000) (lobular cancer, ductal cancer); 8, Karnoub et al. (2007); 9, Turashvili et al. (2007) (ductal cancer). Dark grey boxes, CLU expression in benign breast; medium grey boxes, CLU expression in breast cancer. (B) CLU expression is inversely proportional to the differentiation grade of breast tumour. The box plot representation is from the study by Sørlie et al. (2001). Well-differentiated breast cancer, grade 1; moderately differentiated breast cancer, grade 2; poorly differentiated cancer, grade 3 .

New experimental therapies such as gene therapy, immunotherapy and inhibition of specific cell signalling pathways are currently being investigated to overcome the poor efficacy of current treatments.

Despite the fact that that $C L U$ is down-regulated in the majority of naïve cancer cells (Figs 3A, B and 4A,
B), its expression was found up-regulated in prostate and breast cancer cells resistant to conventional chemotherapy or hormonal therapy (Miyake et al. 2000b,c, Mallory et al. 2005, Ranney et al. 2007). Cappelletti et al. found that $C L U$ is up-regulated in a sub-set of patients bearing breast cancer not responding to the neoadjuvant anti-oestrogen therapy with toremifene. They suggested that this gene might be directly or indirectly involved in the mechanism of resistance to anti-oestrogen (Cappelletti et al. 2008). Others suggested that $C L U$ is involved in the acquisition of chemoresistance by mediating inhibition of TRAIL-triggered apoptosis in docetaxel-resistant PC3 prostate cancer cells (Sallman et al. 2007). Other findings support the hypothesis that silencing $C L U$ expression can enhance the cytotoxicity of chemotherapeutic agents (Trougakos et al. 2004, Redondo et al. 2007, Sowery et al. 2008), as well as IR (Zellweger et al. 2002, Criswell et al. 2005) or androgen ablation therapy (Gleave \& Miyake 2005, Toffanin et al. 2008). Antisense oligonucleotide (ASO) directed against $C L U$ mRNA has been developed and approved for clinical trials (Chi et al. 2005). The $C L U$ ASO is called OGX-011: a 21-mer modified ASO directed against the translation start site located in exon 2. Preclinical data indicate that OGX-011, when given alone, reduced $\mathrm{IC}_{50}$ in $\mathrm{PC} 3$ cells treated with conventional chemotherapeutic drugs, but had no effect on the growth of established PC3 tumours (Miyake et al. 2000a). Treatment of MCF-7 cells with OGX-011 or siRNA against CLU enhanced chemosensitivity to paclitaxel (So et al. 2005). Therefore, $C L U$ has been proposed as an interesting target in CRPC and metastatic breast cancer.

The phase I trial, having a unique pharmacodynamic endpoint, has been completed. The study demonstrated that active concentration of OGX-011 reached prostate cancer tissues and inhibited $C L U$ expression with tolerable side effects (Chi et al. 2005, 2008). A phase II clinical trial in men with high-risk localised $\mathrm{PCa}$ approved by NCI is currently ongoing. The purpose of this trial is to assess the effects of combined therapy with androgen ablation and OGX-011 given prior to radical prostatectomy in men with localised $\mathrm{PCa}$ characterised by high-risk features.

Despite the promising results obtained in vitro in MCF-7 breast cancer cells and in vivo in athymic mice bearing MCF-7 tumours (So et al. 2005), the results of phase II clinical trials recently published are disappointing (Chia et al. 2009). The primary objective of this phase II trial was to assess both safety and efficacy of the combination of OGX-011 and docetaxel for metastatic breast cancer. The clinical goal was to 
reach a response rate in the group treated with the combination of the two agents $\geq 55 \%$. The combination was found well tolerated, but although serum CLU decreased on treatment, there was no relationship observed between the amount of decrease and response. The detected response rate was actually equal to $35 \%$ similar indeed to that expected from the single agent docetaxel. On the basis of these results, the trial did not meet the criteria to proceed to the second stage of accrual (Chia et al. 2009).

\section{Chemoprevention of prostate cancer: a role for CLU in the mechanism of action of green tea catechins}

Chemoprevention is defined as pharmacological intervention with natural or synthetic compounds to prevent, inhibit, delay or reverse carcinogenesis (Sporn et al. 1976). An expanded definition of cancer chemoprevention includes compounds that block neoplastic inception as well as reversing the progression of transformed cells before the appearance of clinically relevant malignant lesions (William et al. 2009).

Prostate cancer represents an ideal target for chemoprevention, because of its high incidence and long latency period before the development of clinically evident disease. Epidemiological and case control studies provide support for the chemopreventive effect of bioactive compounds, such as catechins, extracted from green tea (Jian et al. 2004). The possible anti-cancer activity of green tea catechins (GTCs) may be explained by a number of different mechanisms extensively reviewed by Khan et al. (2006). Epigallocathechin-3-gallate (EGCG), the most abundant catechin contained in green tea, potently inhibited the growth of both SV40-immortalised PNT1A and metastatic PC3 cells, while normal human prostatic epithelial cells were not significantly affected (Caporali et al. 2004). In immortalised and cancer cell lines treated with EGCG, CLU protein was increased, accompanied by cell death markers such as caspase 9, while CLU protein remained undetectable before and after treatment of primary cell cultures at the same doses (Caporali et al. 2004). This result is remarkable, since EGCG and catechins generally inhibit gene expression and protein activity, interfering with the transcription process probably by direct binding. CLU seems to be one of the few genes up-regulated by GTCs.

The TRAMP model of prostate carcinogenesis was developed as an important tool for understanding the progression of PCa (Greenberg et al. 1995). TRAMP mice display in situ and invasive PCa, mimicking the whole spectrum of human prostate cancer progression from prostatic intraepithelial neoplasia (PIN) to androgen-independent disease (Kaplan-Lefko et al. 2003). TRAMP mice express the SV-40 T/t antigens under the control of the prostate-specific, androgendependent minimal rat probasin promoter. Development of prostate cancer in TRAMP mice is thus SV40-driven and age-related. Gupta was first to report GTC effect on TRAMP (Gupta et al. 2001).

We found that $C L U$ expression is down-regulated during prostate cancer progression in the TRAMP mouse model (Caporali et al. 2004). Oral administration of $0.3 \%$ GTCs in drinking water to male TRAMP mice reduced PCa onset from 100 to $20 \%$ without any evidence of adverse events. Animals responding to GTCs displayed recovery of $C L U$ expression followed by reactivation of caspase 9 expression, while those refractory to GTCs, i.e. tumour-bearing mice, did not express either $C L U$ or caspase 9. Both $C L U$ and caspase 9 expressions were determined by IHC as well as western blots of pooled prostates (Caporali et al. 2004, Scaltriti et al. 2006).

Based upon these preclinical findings, we conducted a proof-of principle trial to assess the potential efficacy of GTCs in the prevention of PCa in 60 patients bearing HGPIN, a premalignant lesion associated with increased risk of coexistent PCa (Bettuzzi et al. 2006). The primary endpoint of the study was to determine the impact of GTCs administration on prevalence/progression of PCa. Following one year of treatment, only $1 / 30$ (3\%) of patients who received the green tea polyphenols were diagnosed with cancer compared with $9 / 30(30 \%)$ of the placebo group. In a recent follow-up of the patients in this study (Brausi et al. 2008), a Kaplan-Meier analysis showed $90 \%$ of GTCs-treated patients remained free of cancer diagnosis after 3 years versus $50 \%$ of placebo patients. Preliminary data from our laboratory confirm that $C L U$ is up-regulated in biopsies from GTCs-treated subjects, while it remains unchanged in placebo-treated specimens (Rizzi et al. 2009b). Further work will be necessary in order to understand the role of CLU in GTCs-mediated chemoprevention.

\section{New insights of $C L U$ as tumour modulator: is $C L U$ a new tumour suppressor gene?}

To investigate whether genetic inactivation of $C L U$ in vivo causes phenotypic alterations in the prostate epithelium, we carried out the morphological inspection of the prostate of mice in which $C L U$ had been genetically inactivated. CluKo mice do not show overt 
defects, despite being more prone to cardiac autoimmunity (McLaughlin et al. 2000). Surprisingly, we found advanced PIN or differentiated carcinoma in 100 and $87 \%$ of mice with homozygous or heterozygous deletion of $C L U$. Wild-type siblings did not show any cancer lesions. We found a higher expression of the proliferation marker Ki67 (i.e. higher proliferation index) in the normal portion of prostatic tissue of homo- and heterozygous CluKo mice with regard to wild-type controls (Bettuzzi et al. 2009). We also found that $\mathrm{p} 65 \mathrm{NF}-\kappa \mathrm{B}$ staining was much more intense in the normal portion of the prostate or in low-grade PIN lesions of CluKo mice compared with wild-type controls. NF- $\kappa \mathrm{B}$ plays an important role in the onset of mammalian prostate cancer, being required for prostate cancer cell proliferation and survival (Shukla et al. 2004, 2005, Suh \& Rabson 2004).

To further assess whether prostate tumourigenesis is affected by the loss of $C L U$ expression, we crossed TRAMP mice with CluKo mice. Inactivation of one or both $C L U$ alleles in TRAMP mice led to more advanced invasive disease. Tumour spreading and homing were enhanced in TRAMP/CluKo mice, metastases occurred earlier in ectopic sites and also the survival was decreased; $30 \%$ of the TRAMP-CLU( $-/-)$ mice died by 28 weeks versus none of the TRAMP only mice, $(P<0.01$; Bettuzzi et al. 2009).

Thus, cancer progression is certainly not suppressed or delayed by absence of $C L U$ but, on the contrary, loss of $C L U$ significantly favours the rapid onset of tumour growth. These findings are corroborated by previous results indicating that CluKo mice are also more susceptible than normal mice to chemically induced skin tumourigenesis, suggesting that CLU might be a negative modulator of epithelial cell transformation (Thomas-Tikhonenko et al. 2004).

$C L U$ was also found to act as negative tumour modulator in neuroblastoma. It has been recently proved that the aggressiveness of neuroblastomas arising in MYCN-transgenic mice has significantly increased after deletion of the $C L U$ gene (Chayka et al. 2009). Similar to the effects observed in TRAMP mice, depletion of $C L U$ in MYCN-transgenic mice caused activation of NF- $\kappa \mathrm{B}$ signalling and epithelial-tomesenchymal transition. Thus, inhibiting NF- $\kappa \mathrm{B}$ and maintaining an epithelial phenotype are likely to be critical features of the $C L U$ tumour suppressive functions (Chayka et al. 2009).

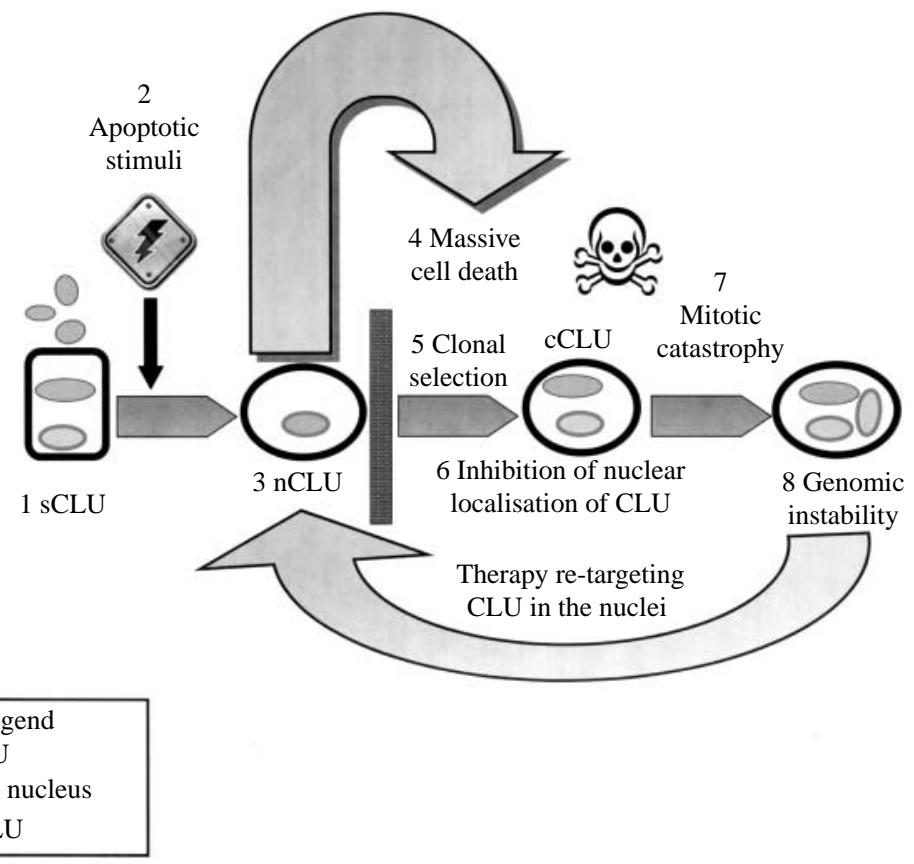

Figure 5 CLU and tumourigenesis. CLU basal level of expression in benign cells is low and confined to sCLU production (1). Following induction of apoptosis by different apoptotic stimuli (2) epithelial cells would switch to production of nCLU (3) which, in turn, would induce programmed cell death mainly through anoikis-driven apoptosis (4). Genetic lesions, which occur during early phases of tumourigenesis, may lead to acquisition of survival advantages resulting in clonal selection (5). Under these conditions, blocking CLU from entering the nucleus would be a key step in the transformation process (6). At this stage, the selection of cells tolerating high levels of cytoplasmic CLU (cCLU) would signal acquisition of a resistant phenotype. This event is associated with impaired mitosis (7), as demonstrated by the production of polynucleated cells (8). A potential new anti-cancer therapy could be based on the re-targeting of CLU in the nuclei to cause commitment of resistant cells to death. 


\section{Conclusions}

Many research teams have produced a great amount of literature and important data on CLU action and tumourigenesis. Nevertheless, contradictions and alternative hypothesis still exist due to different experimental models or tools and to different interpretations. We should now be able to synthesise this enormous amount of data into a better understanding of $C L U$ action.

Is $C L U$ a positive or a negative modulator of mammalian tumourigenesis? Taking the prostate as the paradigm, we know that $C L U$ is the most powerful overexpressed gene during apoptosis-driven rat prostate regression induced by castration or pharmacological androgen ablation (Bettuzzi et al. 1989, Astancolle et al. 2000). If $C L U$ exerts a pro-survival action, why is apoptosis induced and why does the prostate gland shrink concomitantly with $C L U$ overexpression?

Understanding the role of $C L U$ in tumourigenesis is complicated by the different protein forms of CLU. It is also complicated by the time-course of the disease and the selection pressures imposed on the cancer by treatments such as hormone ablation or chemotherapy. $C L U$ is down-regulated in the majority of naïve cancers at the mRNA level, according to Oncomine data. However, up-regulation of $C L U$ is possible in some cancer cells, especially after adjuvant hormonal therapy. Scaltriti et al. (2004a) described that the vast majority of prostate cancer cells were devoid of CLU, but a few nests of morphologically undistinguishable cancer cells had a strong positive signal for CLU. Are these cells already androgen-independent, escaping CLU control?

Scaltriti et al. (2004b) and Moretti et al. (2007) have investigated CLU action by comparing immortalised PNT1A cells (mimicking the early stages of transformation) to metastatic, androgen-independent PC3 cells. In both cell types, nuclear localisation of CLU inhibits cell proliferation, causes cell death and also inhibits cell migration/invasion by interaction with $\alpha$-actinin. Interestingly, following treatment by $C L U$ overexpression through transient transfection, stable cell clones overexpressing $C L U$ emerged which do not show any nuclear localisation of CLU. These cells acquire resistance to apoptosis and tolerate high intracellular cytoplasmic levels of CLU. Thus, does acquisition of resistance to apoptosis require expression of CLU for survival? How important is the inhibition of CLU entering the nucleus?

Is it now possible to reconcile all the experimental results and contributions from different laboratories on the role of $C L U$ in tumourigenesis, even when apparently contradictory? We believe this synthesis is possible and our hypothesis is provided in Fig. 5. Just like many other typical tumour suppressor genes, early-stage-associated events related to physiological action must be distinguished from late-stage-associated ones, when the tumour suppressive factor is inactivated or acquired improper activity. For instance, it has been recently shown that $\mathrm{pRb}$, a paradigmatic tumour suppressor gene, is amplified and plays a promoting role in late-stage colon cancer by suppressing E2F1 and enhancing cell survival by activating the Wnt pathway (Morris et al. 2008).

Figure 5 starts from the general observation that, under physiological conditions, CLU basal level of expression in benign cells is low and confined to sCLU production (point 1). Following induction of apoptosis by different apoptotic stimuli (point 2), epithelial cells would switch to production of nCLU (point 3) which, in turn, would induce programmed-cell death, mainly through anoikis-driven apoptosis (point 4). The process of tumourigenesis is characterised by early genetic lesions, some of which may lead to acquisition of survival advantages, resulting in clonal selection (point 5). Under these conditions, blocking CLU from entering the nucleus would be a key step in the transformation process (point 6). At this stage, the detection of cells tolerating high levels of CLU by intense cytoplasm staining not associated to apoptosis would signal acquisition of a resistant phenotype. This resistant phenotype can continue cell transformation, leading to late-stages associated with impaired mitosis (point 7). In fact, improper mitotic spindle assembling would cause further genomic instability (point 8 ), as demonstrated by the production of polynucleated cells (Scaltriti et al. 2004b). At points $6-8$, a potential new anti-cancer therapy would consist in re-targeting of CLU to the nucleus to commit resistant cells to death.

The hypothesis that $C L U$ may act in vivo as a tumour suppressor gene is supported by a recent study which reports increased penetrance of metastatic neuroblastoma in mice when one or both $C L U$ alleles are deleted (Chayka et al. 2009). These results confirmed our results with CluKo in the TRAMP murine model of prostate cancer (Bettuzzi et al. 2009). Consistent with the hypothesis that $C L U$ is a negative modulator of tumour growth in mammalians, we found that its expression is down-regulated in PCa (Bettuzzi et al. 2000, Scaltriti et al. 2004a, Rizzi et al. 2008), while its expression is restored in TRAMP mice responding to chemoprevention with GTCs (Caporali et al. 2004, Scaltriti et al. 2006). 
No mutations of $C L U$ have been found yet in human cancer, so it is likely that the mechanism of inactivation is epigenetic. This hypothesis is supported by the frequent observation of $\mathrm{CpG}$ island methylation or histone deacetylation in the proximity of the $C L U$ gene in different cancers, including PCa (Lund et al. 2006, Hellebrekers et al. 2007, Suuronen et al. 2007, Rauhala et al. 2008).

How can we reconcile this view with previous findings suggesting that $C L U$ is a pro-survival oncogene? The answer to this important issue probably lies in the fact that the process of tumourigenesis often exploits cellular genes, including tumour suppressor genes, for its own purposes. In a similar manner, we hypothesise that $C L U$ can lead a double life: on the one hand, it suppresses tumourigenesis and metastatic spread by inhibiting NF- $\kappa \mathrm{B}$ activity; on the other hand, highly malignant cells can reactivate $C L U$ expression suppressing NF- $\mathrm{B}$ and survive since a pro-apoptotic NF- $\kappa \mathrm{B}$ signalling is often involved in replication stress induced by chemotherapeutic drugs.

\section{Declaration of interest}

The authors declare that there is no conflict of interest that could be perceived as prejudicing the impartiality of the research reported.

\section{Funding}

This work was supported by grants from the Association for International Cancer Research (AICR Grant No. 06-711) and University of Parma, FIL 2008.

\section{Acknowledgements}

We thank Paul T Wegener for his help in manuscript editing and for profitable discussion.

\section{References}

Andersen CL, Schepeler T, Thorsen K, BirkenkampDemtroder K, Mansilla F, Aaltonen LA, Laurberg S \& Orntoft TF 2007 Clusterin expression in normal mucosa and colorectal cancer. Molecular \& Cellular Proteomics 6 1039-1048.

Astancolle S, Guidetti G, Pinna C, Corti A \& Bettuzzi S 2000 Increased levels of clusterin (SGP-2) mRNA and protein accompany rat ventral prostate involution following finasteride treatment. Journal of Endocrinology 167 197-204.

Bailey RW, Dunker AK, Brown CJ, Garner EC \& Griswold MD 2001 Clusterin, a binding protein with a molten globule-like region. Biochemistry 40 11828-11840.

Bettuzzi S, Hiipakka RA, Gilna P \& Liao ST 1989 Identification of an androgen-repressed mRNA in rat ventral prostate as coding for sulphated glycoprotein 2 by cDNA cloning and sequence analysis. Biochemical Journal 257 293-296.

Bettuzzi S, Davalli P, Astancolle S, Carani C, Madeo B, Tampieri A \& Corti A 2000 Tumor progression is accompanied by significant changes in the levels of expression of polyamine metabolism regulatory genes and clusterin (sulfated glycoprotein 2) in human prostate cancer specimens. Cancer Research 60 28-34.

Bettuzzi S, Brausi M, Rizzi F, Castagnetti G, Peracchia G \& Corti A 2006 Chemoprevention of human prostate cancer by oral administration of green tea catechins in volunteers with high-grade prostate intraepithelial neoplasia: a preliminary report from a one-year proof-of-principle study. Cancer Research 66 1234-1240.

Bettuzzi S, Davalli P, Davoli S, Chayka O, Rizzi F, Belloni L, Pellacani D, Fregni G, Astancolle S, Fassan M et al. 2009 Genetic inactivation of ApoJ/clusterin: effects on prostate tumourigenesis and metastatic spread. Oncogene [in press].

Blaschuk O, Burdzy K \& Fritz IB 1983 Purification and characterization of a cell-aggregating factor (clusterin), the major glycoprotein in ram rete testis fluid. Journal of Biological Chemistry 258 7714-7720.

Brausi M, Rizzi F \& Bettuzzi S 2008 Chemoprevention of human prostate cancer by green tea catechins: two years later. A follow-up update. European Urology 54 472-473.

Burkey BF, deSilva HV \& Harmony JA 1991 Intracellular processing of apolipoprotein $\mathrm{J}$ precursor to the mature heterodimer. Journal of Lipid Research 32 1039-1048.

Caccamo AE, Scaltriti M, Caporali A, D'Arca D, Scorcioni F, Candiano G, Mangiola M \& Bettuzzi S 2003 Nuclear translocation of a clusterin isoform is associated with induction of anoikis in SV40-immortalized human prostate epithelial cells. Annals of the New York Academy of Sciences 1010 514-519.

Caccamo AE, Scaltriti M, Caporali A, D'Arca D, Corti A, Corvetta D, Sala A \& Bettuzzi S $2005 \mathrm{Ca}^{2+}$ depletion induces nuclear clusterin, a novel effector of apoptosis in immortalized human prostate cells. Cell Death and Differentiation 12 101-104.

Caporali A, Davalli P, Astancolle S, D'Arca D, Brausi M, Bettuzzi S \& Corti A 2004 The chemopreventive action of catechins in the TRAMP mouse model of prostate carcinogenesis is accompanied by clusterin overexpression. Carcinogenesis 25 2217-2224.

Cappelletti V, Gariboldi M, De Cecco L, Toffanin S, Reid JF, Lusa L, Bajetta E, Celio L, Greco M, Fabbri A et al. 2008 Patterns and changes in gene expression following neo-adjuvant anti-estrogen treatment in estrogen receptorpositive breast cancer. Endocrine-Related Cancer 15 439-449.

Cervellera M, Raschella G, Santilli G, Tanno B, Ventura A, Mancini C, Sevignani C, Calabretta B \& Sala A 2000 Direct transactivation of the anti-apoptotic gene apolipoprotein J (clusterin) by B-MYB. Journal of Biological Chemistry 275 21055-21060. 
Chayka O, Corvetta D, Dews M, Caccamo AE, Piotrowska I, Santilli G, Gibson S, Sebire NJ, Himoudi N, Hogarty MD et al. 2009 Clusterin, a haploinsufficient tumor suppressor gene in neuroblastomas. Journal of the National Cancer Institute 101 663-677.

Chen T, Turner J, McCarthy S, Scaltriti M, Bettuzzi S \& Yeatman TJ 2004 Clusterin-mediated apoptosis is regulated by adenomatous polyposis coli and is $\mathrm{p} 21$ dependent but p53 independent. Cancer Research 64 7412-7419.

Cheng CY, Chen CL, Feng ZM, Marshall A \& Bardin CW 1988 Rat clusterin isolated from primary Sertoli cell-enriched culture medium is sulfated glycoprotein-2 (SGP-2). Biochemical and Biophysical Research Communications 155 398-404.

Chi KN, Eisenhauer E, Fazli L, Jones EC, Goldenberg SL, Powers J, Tu D \& Gleave ME 2005 A phase I pharmacokinetic and pharmacodynamic study of OGX-011, a 2'-methoxyethyl antisense oligonucleotide to clusterin, in patients with localized prostate cancer. Journal of the National Cancer Institute 97 1287-1296.

Chi KN, Siu LL, Hirte H, Hotte SJ, Knox J, Kollmansberger C, Gleave M, Guns E, Powers J, Walsh W et al. 2008 A phase I study of OGX-011, a 2'-methoxyethyl phosphorothioate antisense to clusterin, in combination with docetaxel in patients with advanced cancer. Clinical Cancer Research 14 833-839.

Chia S, Dent S, Ellard S, Ellis PM, Vandenberg T, Gelmon K, Powers J, Walsh W, Seymour L \& Eisenhauer EA 2009 Phase II trial of OGX-011 in combination with docetaxel in metastatic breast cancer. Clinical Cancer Research $\mathbf{1 5}$ 708-713.

Choi NH, Mazda T \& Tomita M 1989 A serum protein SP40,40 modulates the formation of membrane attack complex of complement on erythrocytes. Molecular Immunology 26 835-840.

Choi-Miura NH, Takahashi Y, Nakano Y, Tobe T \& Tomita M 1992 Identification of the disulfide bonds in human plasma protein SP-40,40 (apolipoprotein-J). Journal of Biochemistry 112 557-561.

Cochrane DR, Wang Z, Muramaki M, Gleave ME \& Nelson CC 2007 Differential regulation of clusterin and its isoforms by androgens in prostate cells. Journal of Biological Chemistry 282 2278-2287.

Collard MW \& Griswold MD 1987 Biosynthesis and molecular cloning of sulfated glycoprotein 2 secreted by rat Sertoli cells. Biochemistry 26 3297-3303.

Criswell T, Beman M, Araki S, Leskov K, Cataldo E, Mayo LD \& Boothman DA 2005 Delayed activation of insulin-like growth factor-1 receptor/Src/MAPK/Egr-1 signaling regulates clusterin expression, a pro-survival factor. Journal of Biological Chemistry 280 14212-14221.

Devauchelle V, Essabbani A, De Pinieux G, Germain S, Tourneur L, Mistou S, Margottin-Goguet F, Anract P, Migaud H, Le Nen D et al. 2006 Characterization and functional consequences of underexpression of clusterin in rheumatoid arthritis. Journal of Immunology 177 6471-6479.

Dhanasekaran SM, Barrette TR, Ghosh D, Shah R, Varambally S, Kurachi K, Pienta KJ, Rubin MA \& Chinnaiyan AM 2001 Delineation of prognostic biomarkers in prostate cancer. Nature 412 822-826.

Dhanasekaran SM, Dash A, Yu J, Maine IP, Laxman B, Tomlins SA, Creighton CJ, Menon A, Rubin MA \& Chinnaiyan AM 2005 Molecular profiling of human prostate tissues: insights into gene expression patterns of prostate development during puberty. FASEB Journal 19 243-245.

Finak G, Bertos N, Pepin F, Sadekova S, Souleimanova M, Zhao H, Chen H, Omeroglu G, Meterissian S, Omeroglu A et al. 2008 Stromal gene expression predicts clinical outcome in breast cancer. Nature Medicine 14 518-527.

Fischer-Colbrie R, Zangerle R, Frischenschlager I, Weber A \& Winkler H 1984 Isolation and immunological characterization of a glycoprotein from adrenal chromaffin granules. Journal of Neurochemistry $\mathbf{4 2}$ 1008-1016.

French LE, Chonn A, Ducrest D, Baumann B, Belin D, Wohlwend A, Kiss JZ, Sappino AP, Tschopp J \& Schifferli JA 1993 Murine clusterin: molecular cloning and mRNA localization of a gene associated with epithelial differentiation processes during embryogenesis. Journal of Cell Biology 122 1119-1130.

Fritz IB, Burdzy K, Setchell B \& Blaschuk O 1983 Ram rete testis fluid contains a protein (clusterin) which influences cell-cell interactions in vitro. Biology of Reproduction $\mathbf{2 8}$ 1173-1188.

Gleave M \& Miyake H 2005 Use of antisense oligonucleotides targeting the cytoprotective gene, clusterin, to enhance androgen- and chemo-sensitivity in prostate cancer. World Journal of Urology 23 38-46.

Gonzalez-Angulo AM, Morales-Vasquez F \& Hortobagyi GN 2007 Overview of resistance to systemic therapy in patients with breast cancer. Advances in Experimental Medicine and Biology 608 1-22.

Greenberg NM, DeMayo F, Finegold MJ, Medina D, Tilley WD, Aspinall JO, Cunha GR, Donjacour AA, Matusik RJ \& Rosen JM 1995 Prostate cancer in a transgenic mouse. PNAS 92 3439-3443.

Gupta S, Hastak K, Ahmad N, Lewin JS \& Mukhtar H 2001 Inhibition of prostate carcinogenesis in TRAMP mice by oral infusion of green tea polyphenols. PNAS 98 10350-10355.

Hellebrekers DM, Melotte V, Vire E, Langenkamp E, Molema G, Fuks F, Herman JG, Van Criekinge W, Griffioen AW \& van Engeland M 2007 Identification of epigenetically silenced genes in tumor endothelial cells. Cancer Research 67 4138-4148.

Holzbeierlein J, Lal P, LaTulippe E, Smith A, Satagopan J, Zhang L, Ryan C, Smith S, Scher H, Scardino P et al. 2004 Gene expression analysis of human prostate 
carcinoma during hormonal therapy identifies androgenresponsive genes and mechanisms of therapy resistance. American Journal of Pathology 164 217-227.

Horton P, Park KJ, Obayashi T, Fujita N, Harada H, AdamsCollier CJ \& Nakai K 2007 WoLF PSORT: protein localization predictor. Nucleic Acids Research 35 W585-W587.

Humphreys DT, Carver JA, Easterbrook-Smith SB \& Wilson MR 1999 Clusterin has chaperone-like activity similar to that of small heat shock proteins. Journal of Biological Chemistry 274 6875-6881.

Itahana Y, Piens M, Sumida T, Fong S, Muschler J \& Desprez PY 2007 Regulation of clusterin expression in mammary epithelial cells. Experimental Cell Research 313 943-951.

James RW, Hochstrasser AC, Borghini I, Martin B, Pometta D \& Hochstrasser D 1991 Characterization of a human high density lipoprotein-associated protein, NA1/NA2. Identity with SP-40,40, an inhibitor of complement-mediated cytolysis. Arteriosclerosis, Thrombosis, and Vascular Biology 11 645-652.

Jenne DE \& Tschopp J 1989 Molecular structure and functional characterization of a human complement cytolysis inhibitor found in blood and seminal plasma: identity to sulfated glycoprotein 2, a constituent of rat testis fluid. PNAS 86 7123-7127.

Jian L, Xie LP, Lee AH \& Binns CW 2004 Protective effect of green tea against prostate cancer: a case-control study in southeast China. International Journal of Cancer 108 130-135.

Jin G \& Howe PH 1999 Transforming growth factor beta regulates clusterin gene expression via modulation of transcription factor c-Fos. European Journal of Biochemistry 263 534-542.

Jordan-Starck TC, Lund SD, Witte DP, Aronow BJ, Ley CA, Stuart WD, Swertfeger DK, Clayton LR, Sells SF, Paigen B et al. 1994 Mouse apolipoprotein J: characterization of a gene implicated in atherosclerosis. Journal of Lipid Research 35 194-210.

July LV, Akbari M, Zellweger T, Jones EC, Goldenberg SL \& Gleave ME 2002 Clusterin expression is significantly enhanced in prostate cancer cells following androgen withdrawal therapy. Prostate 50 179-188.

Kang SW, Shin YJ, Shim YJ, Jeong SY, Park IS \& Min BH 2005 Clusterin interacts with SCLIP (SCG10-like protein) and promotes neurite outgrowth of PC12 cells. Experimental Cell Research 309 305-315.

Kaplan-Lefko PJ, Chen TM, Ittmann MM, Barrios RJ, Ayala GE, Huss WJ, Maddison LA, Foster BA \& Greenberg NM 2003 Pathobiology of autochthonous prostate cancer in a pre-clinical transgenic mouse model. Prostate 55 219-237.

Karnoub AE, Dash AB, Vo AP, Sullivan A, Brooks MW, Bell GW, Richardson AL, Polyak K, Tubo R \& Weinberg RA 2007 Mesenchymal stem cells within tumour stroma promote breast cancer metastasis. Nature 449 557-563.

Khan N, Afaq F, Saleem M, Ahmad N \& Mukhtar H 2006

Targeting multiple signaling pathways by green tea polyphenol (-)-epigallocatechin-3-gallate. Cancer Research 66 2500-2505.

Kirszbaum L, Sharpe JA, Murphy B, d'Apice AJ, Classon B, Hudson P \& Walker ID 1989 Molecular cloning and characterization of the novel, human complement-associated protein, SP-40,40: a link between the complement and reproductive systems. EMBO Journal 8 711-718.

Kirszbaum L, Bozas SE \& Walker ID 1992 SP-40,40, a protein involved in the control of the complement pathway, possesses a unique array of disulphide bridges. FEBS Letters 297 70-76.

Klock G, Storch S, Rickert J, Gutacker C \& Koch-Brandt C 1998 Differential regulation of the clusterin gene by Ha-ras and c-myc oncogenes and during apoptosis. Journal of Cellular Physiology 177 593-605.

Klokov D, Criswell T, Leskov KS, Araki S, Mayo L \& Boothman DA 2004 IR-inducible clusterin gene expression: a protein with potential roles in ionizing radiation-induced adaptive responses, genomic instability, and bystander effects. Mutation Research 568 97-110.

Kruger S, Ola V, Fischer D, Feller AC \& Friedrich M 2007 Prognostic significance of clusterin immunoreactivity in breast cancer. Neoplasia 54 46-50.

Kyprianou N, English HF, Davidson NE \& Isaacs JT 1991 Programmed cell death during regression of the MCF-7 human breast cancer following estrogen ablation. Cancer Research 51 162-166.

Lakins JN, Poon S, Easterbrook-Smith SB, Carver JA, Tenniswood MP \& Wilson MR 2002 Evidence that clusterin has discrete chaperone and ligand binding sites. Biochemistry 41 282-291.

Lapointe J, Li C, Higgins JP, van de Rijn M, Bair E, Montgomery K, Ferrari M, Egevad L, Rayford W, Bergerheim U et al. 2004 Gene expression profiling identifies clinically relevant subtypes of prostate cancer. PNAS 101 811-816.

LaTulippe E, Satagopan J, Smith A, Scher H, Scardino P, Reuter V \& Gerald WL 2002 Comprehensive gene expression analysis of prostate cancer reveals distinct transcriptional programs associated with metastatic disease. Cancer Research 62 4499-4506.

Law GL \& Griswold MD 1994 Activity and form of sulfated glycoprotein 2 (clusterin) from cultured Sertoli cells, testis, and epididymis of the rat. Biology of Reproduction 50 669-679.

Lee C, Atanelov L, Modrek B \& Xing Y 2003 ASAP: the Alternative Splicing Annotation Project. Nucleic Acids Research 31 101-105.

Leskov KS, Criswell T, Antonio S, Li J, Yang CR, Kinsella TJ \& Boothman DA 2001 When X-ray-inducible proteins meet DNA double strand break repair. Seminars in Radiation Oncology 11 352-372.

Leskov KS, Klokov DY, Li J, Kinsella TJ \& Boothman DA 2003 Synthesis and functional analyses of nuclear clusterin, a cell death protein. Journal of Biological Chemistry 278 11590-11600. 
Li X, Massa PE, Hanidu A, Peet GW, Aro P, Savitt A, Mische S, Li J \& Marcu KB 2002 IKKalpha, IKKbeta, and NEMO/IKKgamma are each required for the NF-kappa B-mediated inflammatory response program. Journal of Biological Chemistry 277 45129-45140.

Loison F, Debure L, Nizard P, le Goff P, Michel D \& le Drean Y 2006 Up-regulation of the clusterin gene after proteotoxic stress: implication of HSF1-HSF2 heterocomplexes. Biochemical Journal 395 223-231.

Lund P, Weisshaupt K, Mikeska T, Jammas D, Chen X, Kuban RJ, Ungethum U, Krapfenbauer U, Herzel HP, Schafer R et al. 2006 Oncogenic HRAS suppresses clusterin expression through promoter hypermethylation. Oncogene 25 4890-4903.

Luo JH, Yu YP, Cieply K, Lin F, Deflavia P, Dhir R, Finkelstein S, Michalopoulos G \& Becich M 2002 Gene expression analysis of prostate cancers. Molecular Carcinogenesis 33 25-35.

Mallory JC, Crudden G, Oliva A, Saunders C, Stromberg A \& Craven RJ 2005 A novel group of genes regulates susceptibility to antineoplastic drugs in highly tumorigenic breast cancer cells. Molecular Pharmacology 68 1747-1756.

Markopoulou S, Kontargiris E, Batsi C, Tzavaras T, Trougakos I, Boothman DA, Gonos ES \& Kolettas E 2009 Vanadium-induced apoptosis of $\mathrm{HaCaT}$ cells is mediated by c-fos and involves nuclear accumulation of clusterin. FEBS Journal.

McLaughlin L, Zhu G, Mistry M, Ley-Ebert C, Stuart WD, Florio CJ, Groen PA, Witt SA, Kimball TR, Witte DP et al. 2000 Apolipoprotein J/clusterin limits the severity of murine autoimmune myocarditis. Journal of Clinical Investigation 106 1105-1113.

Michel D, Gillet G, Volovitch M, Pessac B, Calothy G \& Brun G 1989 Expression of a novel gene encoding a 51.5 $\mathrm{kD}$ precursor protein is induced by different retroviral oncogenes in quail neuroretinal cells. Oncogene Research 4 127-136.

Michel D, Chatelain G, North S \& Brun G 1997 Stressinduced transcription of the clusterin/apoJ gene. Biochemical Journal 328 45-50.

Miyake H, Chi KN \& Gleave ME 2000a Antisense TRPM-2 oligodeoxynucleotides chemosensitize human androgenindependent PC-3 prostate cancer cells both in vitro and in vivo. Clinical Cancer Research 6 1655-1663.

Miyake H, Nelson C, Rennie PS \& Gleave ME $2000 b$ Testosterone-repressed prostate message- 2 is an antiapoptotic gene involved in progression to androgen independence in prostate cancer. Cancer Research 60 170-176.

Miyake H, Nelson C, Rennie PS \& Gleave ME 2000c Acquisition of chemoresistant phenotype by overexpression of the antiapoptotic gene testosterone-repressed prostate message-2 in prostate cancer xenograft models. Cancer Research 60 2547-2554.

Montpetit ML, Lawless KR \& Tenniswood M 1986 Androgen-repressed messages in the rat ventral prostate. Prostate 8 25-36.
Moretti RM, Marelli MM, Mai S, Cariboni A, Scaltriti M, Bettuzzi S \& Limonta P 2007 Clusterin isoforms differentially affect growth and motility of prostate cells: possible implications in prostate tumorigenesis. Cancer Research 67 10325-10333.

Morris EJ, Ji JY, Yang F, Di Stefano L, Herr A, Moon NS, Kwon EJ, Haigis KM, Naar AM \& Dyson NJ 2008 E2F1 represses beta-catenin transcription and is antagonized by both $\mathrm{pRB}$ and CDK8. Nature $\mathbf{4 5 5}$ 552-556.

Murphy BF, Kirszbaum L, Walker ID \& d'Apice AJ 1988 SP-40,40, a newly identified normal human serum protein found in the SC5b-9 complex of complement and in the immune deposits in glomerulonephritis. Journal of Clinical Investigation 81 1858-1864.

Nizard P, Tetley S, Le Drean Y, Watrin T, Le Goff P, Wilson MR \& Michel D 2007 Stress-induced retrotranslocation of clusterin/ApoJ into the cytosol. Traffic 8 554-565.

Nuutinen T, Suuronen T, Kyrylenko S, Huuskonen J \& Salminen A 2005 Induction of clusterin/apoJ expression by histone deacetylase inhibitors in neural cells. Neurochemistry International 47 528-538.

O'Bryan MK, Baker HW, Saunders JR, Kirszbaum L, Walker ID, Hudson P, Liu DY, Glew MD, d'Apice AJ \& Murphy BF 1990 Human seminal clusterin (SP-40,40). Isolation and characterization. Journal of Clinical Investigation 85 1477-1486.

Perou CM, Sørlie T, Eisen MB, van de Rijn M, Jeffrey SS, Rees CA, Pollack JR, Ross DT, Johnsen H, Akslen LA et al. 2000 Molecular portraits of human breast tumours. Nature 406 747-752.

Pins MR, Fiadjoe JE, Korley F, Wong M, Rademaker AW, Jovanovic B, Yoo TK, Kozlowski JM, Raji A, Yang XJ et al. 2004 Clusterin as a possible predictor for biochemical recurrence of prostate cancer following radical prostatectomy with intermediate Gleason scores: a preliminary report. Prostate Cancer and Prostatic Disease 7 243-248.

Poon S, Easterbrook-Smith SB, Rybchyn MS, Carver JA \& Wilson MR 2000 Clusterin is an ATP-independent chaperone with very broad substrate specificity that stabilizes stressed proteins in a folding-competent state. Biochemistry 39 15953-15960.

Pucci S, Bonanno E, Pichiorri F, Angeloni C \& Spagnoli LG 2004 Modulation of different clusterin isoforms in human colon tumorigenesis. Oncogene 23 2298-2304.

Radvanyi L, Singh-Sandhu D, Gallichan S, Lovitt C, Pedyczak A, Mallo G, Gish K, Kwok K, Hanna W, Zubovits J et al. 2005 The gene associated with trichorhinophalangeal syndrome in humans is overexpressed in breast cancer. PNAS 102 11005-11010.

Ranney MK, Ahmed IS, Potts KR \& Craven RJ 2007 Multiple pathways regulating the anti-apoptotic protein clusterin in breast cancer. Biochimica et Biophysica Acta 1772 1103-1111. 
Rauhala HE, Porkka KP, Saramaki OR, Tammela TL \& Visakorpi T 2008 Clusterin is epigenetically regulated in prostate cancer. International Journal of Cancer $\mathbf{1 2 3}$ 1601-1609.

Reddy KB, Jin G, Karode MC, Harmony JA \& Howe PH 1996 Transforming growth factor beta (TGF beta)induced nuclear localization of apolipoprotein $\mathrm{J} /$ clusterin in epithelial cells. Biochemistry 35 6157-6163.

Redondo M, Villar E, Torres-Munoz J, Tellez T, Morell M \& Petito CK 2000 Overexpression of clusterin in human breast carcinoma. American Journal of Pathology 157 393-399.

Redondo M, Tellez T, Roldan MJ, Serrano A, Garcia-Aranda M, Gleave ME, Hortas ML \& Morell M 2007 Anticlusterin treatment of breast cancer cells increases the sensitivities of chemotherapy and tamoxifen and counteracts the inhibitory action of dexamethasone on chemotherapy-induced cytotoxicity. Breast Cancer Research 9 R86.

Rhodes DR, Yu J, Shanker K, Deshpande N, Varambally R, Ghosh D, Barrette T, Pandey A \& Chinnaiyan AM 2004 ONCOMINE: a cancer microarray database and integrated data-mining platform. Neoplasia 6 1-6.

Richardson AL, Wang ZC, De Nicolo A, Lu X, Brown M, Miron A, Liao X, Iglehart JD, Livingston DM \& Ganesan S 2006 X chromosomal abnormalities in basal-like human breast cancer. Cancer Cell 9 121-132.

Rizzi F, Belloni L, Crafa P, Lazzaretti M, Remondini D, Ferretti S, Cortellini P, Corti A \& Bettuzzi S 2008 A novel gene signature for molecular diagnosis of human prostate cancer by RT-qPCR. PLOS ONE 3 e3617.

Rizzi F, Caccamo AE, Belloni L \& Bettuzzi S 2009a Clusterin is a short half-life, poly-ubiquitinated protein, which controls the fate of prostate cancer cells. Journal of Cellular Physiology 219 314-323.

Rizzi F, Troglio MG, Brausi M \& Bettuzzi S 2009b Clusterin gene expression as a novel biomarker of response with GTE in humans. European Urology Supplements 8345.

Rosenberg ME \& Silkensen J 1995 Clusterin: physiologic and pathophysiologic considerations. International Journal of Biochemistry and Cell Biology 27 633-645.

Sallman DA, Chen X, Zhong B, Gilvary DL, Zhou J, Wei S \& Djeu JY 2007 Clusterin mediates TRAIL resistance in prostate tumor cells. Molecular Cancer Therapeutics 6 2938-2947.

Santilli G, Aronow BJ \& Sala A 2003 Essential requirement of apolipoprotein $\mathbf{J}$ (clusterin) signaling for IkappaB expression and regulation of NF-kappaB activity. Journal of Biological Chemistry 278 38214-38219.

Savkovic V, Gantzer H, Reiser U, Selig L, Gaiser S, Sack U, Kloppel G, Mossner J, Keim V, Horn F et al. 2007 Clusterin is protective in pancreatitis through anti-apoptotic and anti-inflammatory properties. Biochemical and Biophysical Research Communications 356 431-437.
Scaltriti M, Brausi M, Amorosi A, Caporali A, D’Arca D, Astancolle S, Corti A \& Bettuzzi S 2004a Clusterin (SGP-2, ApoJ) expression is downregulated in low- and high-grade human prostate cancer. International Journal of Cancer 108 23-30.

Scaltriti M, Santamaria A, Paciucci R \& Bettuzzi S 2004b Intracellular clusterin induces $\mathrm{G} 2-\mathrm{M}$ phase arrest and cell death in PC-3 prostate cancer cells1. Cancer Research 64 6174-6182.

Scaltriti M, Belloni L, Caporali A, Davalli P, Remondini D, Rizzi F, Astancolle S, Corti A \& Bettuzzi S 2006 Molecular classification of green tea catechin-sensitive and green tea catechin-resistant prostate cancer in the TRAMP mice model by quantitative real-time PCR gene profiling. Carcinogenesis 27 1047-1053.

Schepeler T, Mansilla F, Christensen LL, Orntoft TF \& Andersen CL 2007 Clusterin expression can be modulated by changes in TCF1-mediated Wnt signaling. Journal of Molecular Signaling 26.

Shannan B, Seifert M, Leskov K, Willis J, Boothman D, Tilgen W \& Reichrath J 2006 Challenge and promise: roles for clusterin in pathogenesis, progression and therapy of cancer. Cell Death and Differentiation 13 12-19.

Shukla S, MacLennan GT, Fu P, Patel J, Marengo SR, Resnick MI \& Gupta S 2004 Nuclear factor-kappaB/p65 (Rel A) is constitutively activated in human prostate adenocarcinoma and correlates with disease progression. Neoplasia 6 390-400.

Shukla S, Maclennan GT, Marengo SR, Resnick MI \& Gupta S 2005 Constitutive activation of P I3 K-Akt and NF-kappaB during prostate cancer progression in autochthonous transgenic mouse model. Prostate 64 224-239.

de Silva HV, Harmony JA, Stuart WD, Gil CM \& Robbins J 1990 a Apolipoprotein J: structure and tissue distribution. Biochemistry 29 5380-5389.

de Silva HV, Stuart WD, Park YB, Mao SJ, Gil CM, Wetterau JR, Busch SJ \& Harmony JA $1990 b$ Purification and characterization of apolipoprotein. Journal of Biological Chemistry 265 14292-14297.

Singh D, Febbo PG, Ross K, Jackson DG, Manola J, Ladd C, Tamayo P, Renshaw AA, D'Amico AV, Richie JP et al. 2002 Gene expression correlates of clinical prostate cancer behavior. Cancer Cell 1 203-209.

So A, Sinnemann S, Huntsman D, Fazli L \& Gleave M 2005 Knockdown of the cytoprotective chaperone, clusterin, chemosensitizes human breast cancer cells both in vitro and in vivo. Molecular Cancer Therapeutics 4 1837-1849.

Sørlie T, Perou CM, Tibshirani R, Aas T, Geisler S, Johnson H, Hastie T, Eisen MB, van de Rijn M, Jeffrey SS et al. 2001 Gene expression patterns of breast carcinomas distinguish tumor subclasses with clinical implications. PNAS $\mathbf{9 8}$ 10869-10874.

Sowery RD, Hadaschik BA, So AI, Zoubeidi A, Fazli L, Hurtado-Coll A \& Gleave ME 2008 Clusterin knockdown 
using the antisense oligonucleotide OGX-011 re-sensitizes docetaxel-refractory prostate cancer PC-3 cells to chemotherapy. British Journal of Urolgy International 102 389-397.

Sporn MB, Dunlop NM, Newton DL \& Smith JM 1976 Prevention of chemical carcinogenesis by vitamin A and its synthetic analogs (retinoids). Federation Proceedings 35 1332-1338.

Suh J \& Rabson AB 2004 NF-kappaB activation in human prostate cancer: important mediator or epiphenomenon? Journal of Cellular Biochemistry 91 100-117.

Suuronen T, Nuutinen T, Ryhanen T, Kaarniranta K \& Salminen A 2007 Epigenetic regulation of clusterin/ apolipoprotein $\mathrm{J}$ expression in retinal pigment epithelial cells. Biochemical and Biophysical Research Communications 357 397-401.

Takase O, Marumo T, Hishikawa K, Fujita T, Quigg RJ \& Hayashi M $2008 a$ NF-kappaB-dependent genes induced by proteinuria and identified using DNA microarrays. Clinical and Experimental Nephrology 12 181-188.

Takase O, Minto AW, Puri TS, Cunningham PN, Jacob A, Hayashi M \& Quigg RJ 2008b Inhibition of NFkappaB-dependent Bcl-xL expression by clusterin promotes albumin-induced tubular cell apoptosis. Kidney International 73 567-577.

Thomas-Tikhonenko A, Viard-Leveugle I, Dews M, Wehrli P, Sevignani C, Yu D, Ricci S, el-Deiry W, Aronow B, Kaya G et al. 2004 Myc-transformed epithelial cells down-regulate clusterin, which inhibits their growth in vitro and carcinogenesis in vivo. Cancer Research 64 3126-3136.

Toffanin S, Daidone MG, Miodini P, De Cecco L, Gandellini P \& Cappelletti V 2008 Clusterin: a potential target for improving response to antiestrogens. International Journal of Oncology 33 791-798.

Tomlins SA, Mehra R, Rhodes DR, Cao X, Wang L, Dhanasekaran SM, Kalyana-Sundaram S, Wei JT, Rubin MA, Pienta KJ et al. 2007 Integrative molecular concept modeling of prostate cancer progression. Nature Genetics 39 41-51.

Trougakos IP \& Gonos ES 2002 Clusterin/apolipoprotein J in human aging and cancer. International Journal of Biochemistry \& Cell Biology 34 1430-1448.

Trougakos IP, So A, Jansen B, Gleave ME \& Gonos ES 2004 Silencing expression of the clusterin/apolipoprotein $\mathrm{j}$ gene in human cancer cells using small interfering RNA induces spontaneous apoptosis, reduced growth ability, and cell sensitization to genotoxic and oxidative stress. Cancer Research 64 1834-1842.

Turashvili G, Bouchal J, Baumforth K, Wei W, Dziechciarkova M, Ehrmann J, Klein J, Fridman E, Skarda J, Srovnal J et al. 2007 Novel markers for differentiation of lobular and ductal invasive breast carcinomas by laser microdissection and microarray analysis. BMC Cancer 755.

Vanaja DK, Cheville JC, Iturria SJ \& Young CY 2003 Transcriptional silencing of zinc finger protein 185 identified by expression profiling is associated with prostate cancer progression. Cancer Research 63 3877-3882.

Varambally S, Yu J, Laxman B, Rhodes DR, Mehra R, Tomlins SA, Shah RB, Chandran U, Monzon FA, Becich MJ et al. 2005 Integrative genomic and proteomic analysis of prostate cancer reveals signatures of metastatic progression. Cancer Cell 8 393-406.

Welsh JB, Sapinoso LM, Su AI, Kern SG, Wang-Rodriguez J, Moskaluk CA, Frierson HF Jr \& Hampton GM 2001 Analysis of gene expression identifies candidate markers and pharmacological targets in prostate cancer. Cancer Research 61 5974-5978.

William WN Jr, Heymach JV, Kim ES \& Lippman SM 2009 Molecular targets for cancer chemoprevention. Nature Reviews. Drug Discovery 8 213-225.

Wilson MR \& Easterbrook-Smith SB 2000 Clusterin is a secreted mammalian chaperone. Trends in Biochemical Sciences 25 95-98.

Wong P, Pineault J, Lakins J, Taillefer D, Leger J, Wang C \& Tenniswood M 1993 Genomic organization and expression of the rat TRPM-2 (clusterin) gene, a gene implicated in apoptosis. Journal of Biological Chemistry 268 5021-5031.

Wong P, Taillefer D, Lakins J, Pineault J, Chader G \& Tenniswood M 1994 Molecular characterization of human TRPM-2/clusterin, a gene associated with sperm maturation, apoptosis and neurodegeneration. European Journal of Biochemistry 221 917-925.

Xie MJ, Motoo Y, Su SB, Mouri H, Ohtsubo K, Matsubara F \& Sawabu N 2002 Expression of clusterin in human pancreatic cancer. Pancreas 25 234-238.

Xie D, Lau SH, Sham JS, Wu QL, Fang Y, Liang LZ, Che LH, Zeng YX \& Guan XY 2005 Up-regulated expression of cytoplasmic clusterin in human ovarian carcinoma. Cancer 103 277-283.

Yang CR, Leskov K, Hosley-Eberlein K, Criswell T, Pink JJ, Kinsella TJ \& Boothman DA 2000 Nuclear clusterin/XIP8, an X-ray-induced $\mathrm{Ku} 70$ binding protein that signals cell death. PNAS 97 5907-5912.

Yu YP, Landsittel D, Jing L, Nelson J, Ren B, Liu L, McDonald C, Thomas R, Dhir R, Finkelstein S et al. 2004 Gene expression alterations in prostate cancer predicting tumor aggression and preceding development of malignancy. Journal of Clinical Oncology 22 2790-2799.

Zellweger T, Chi K, Miyake H, Adomat H, Kiyama S, Skov K \& Gleave ME 2002 Enhanced radiation sensitivity in prostate cancer by inhibition of the cell survival protein clusterin. Clinical Cancer Research 8 3276-3284.

Zhang LY, Ying WT, Mao YS, He HZ, Liu Y, Wang HX, Liu F, Wang K, Zhang DC, Wang Y et al. 2003 Loss of clusterin both in serum and tissue correlates with the tumorigenesis of esophageal squamous cell carcinoma via proteomics approaches. World Journal of Gastroenterology 9 650-654. 